\title{
Perspective: Potential Impact and Therapeutic Implications of Oncogenic PI3K Activation on Chromosomal Instability
}

\author{
Bart Vanhaesebroeck $^{1, * \mathbb{C}}$, Benoit Bilanges ${ }^{1}$, Ralitsa R. Madsen ${ }^{2}{ }^{\mathbb{D}}$, Katie L. Dale ${ }^{1}$, Evelyn Lau ${ }^{1}$ \\ and Elina Vladimirou $1, * \mathbb{D}$ \\ 1 UCL Cancer Institute, University College London, 72 Huntley Street, London WC1E 6BT, UK \\ 2 Centre for Cardiovascular Sciences, Queens Medical Research Institute, University of Edinburgh, \\ 47 Little France Crescent, Edinburgh EH16 4TJ, UK \\ * Correspondence: bart.vanh@ucl.ac.uk (B.V.); e.vladimirou@ucl.ac.uk (E.V.)
}

Received: 21 July 2019; Accepted: 31 July 2019; Published: 1 August 2019

check for updates

\begin{abstract}
Genetic activation of the class I PI3K pathway is very common in cancer. This mostly results from oncogenic mutations in PIK3CA, the gene encoding the ubiquitously expressed PI $3 \mathrm{~K} \alpha$ catalytic subunit, or from inactivation of the PTEN tumour suppressor, a lipid phosphatase that opposes class I PI3K signalling. The clinical impact of PI3K inhibitors in solid tumours, aimed at dampening cancer-cell-intrinsic PI3K activity, has thus far been limited. Challenges include poor drug tolerance, incomplete pathway inhibition and pre-existing or inhibitor-induced resistance. The principle of pharmacologically targeting cancer-cell-intrinsic PI3K activity also assumes that all cancer-promoting effects of PI3K activation are reversible, which might not be the case. Emerging evidence suggests that genetic PI3K pathway activation can induce and/or allow cells to tolerate chromosomal instability, which - even if occurring in a low fraction of the cell population-might help to facilitate and/or drive tumour evolution. While it is clear that such genomic events cannot be reverted pharmacologically, a role for PI3K in the regulation of chromosomal instability could be exploited by using PI3K pathway inhibitors to prevent those genomic events from happening and/or reduce the pace at which they are occurring, thereby dampening cancer development or progression. Such an impact might be most effective in tumours with clonal PI3K activation and achievable at lower drug doses than the maximum-tolerated doses of PI3K inhibitors currently used in the clinic.
\end{abstract}

Keywords: PI3-kinase; chromosomal instability; PI3K inhibitor; cancer; tumour evolution; centrosome

\section{Introduction}

In this section, we provide a general introduction to PI3K and chromosomal instability, and describe in Section 2 how deregulated PI3K activity can affect chromosomal instability.

\subsection{Class I PI3Ks-PIK3CA Mutation and Amplification}

Class I PI3Ks are lipid kinases that signal downstream of tyrosine kinases, G protein-coupled receptors and small GTPases such as Ras, cdc42 and Rac (Figure 1A) and convert the membrane-bound lipid phosphatidylinositol $(4,5)$ bisphosphate $\left(\mathrm{PI}(4,5) \mathrm{P}_{2}\right)$ to phosphatidylinositol $(3,4,5)$ trisphosphate $\left(\mathrm{PI}(3,4,5) \mathrm{P}_{3}\right.$; also known as $\left.\mathrm{PIP}_{3}\right)$. This lipid, together with its degradation product $\mathrm{PI}(3,4) \mathrm{P}_{2}$, regulates downstream signalling cascades involving $\mathrm{Akt} / \mathrm{PKB}, \mathrm{mTORC} 1 / 2$ and other proteins, ultimately inducing anabolic metabolism, cell-cycle progression, migration and pro-survival functions [1,2]. PIP 3 and $\mathrm{PI}(3,4) \mathrm{P}_{2}$ are both substrates for dephosphorylation at the $3^{\prime}$ position by the PTEN lipid phosphatase, 
effectively antagonising PI3K function. PTEN is a tumour suppressor whose frequent inactivation in cancer disrupts the normal dampening of class I PI3K signalling [3].

A.



B.

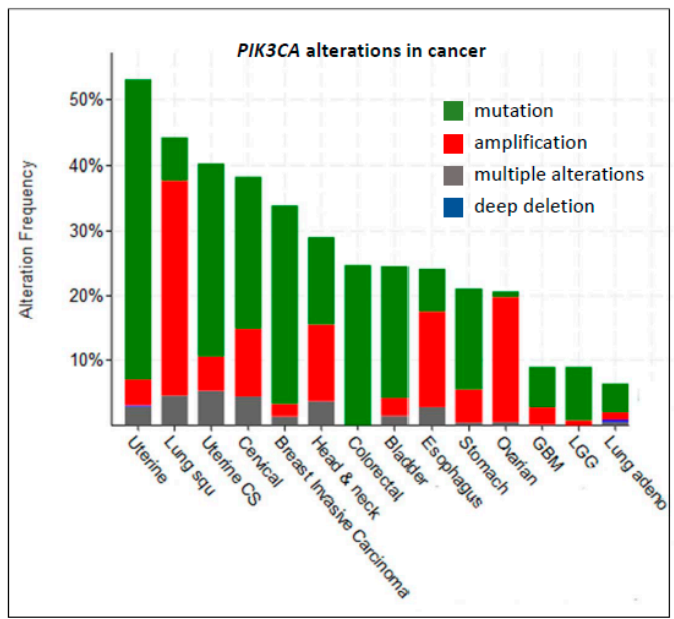

Figure 1. (A) Overview of class I PI3K signalling and genetic alterations in PI3K catalytic subunits in cancer. * Note that both wild-type and mutant PIK3CA alleles can be amplified in cancer [4]. A recent analysis showed that $P I K 3 C A$-mutant cancers frequently have more than one copy of the mutated PIK3CA gene and/or harbour a second PIK3CA variant [4]. (B) Frequency of PIK3CA alterations in a range of human cancers. Data are from cBioportal [5,6] (accessed June 2019).

Mammals have four class I PI3K catalytic isoforms (p110 $\alpha, \beta, \gamma$ and $\delta$ ), encoded by four distinct genes, PIK3CA, PIK3CB, PIK3CG and PIK3CD (Figure 1A). The class IA subset of catalytic PI3Ks (p110 $\alpha$, $\beta$ and $\delta$ ) occur in a heterodimeric complex with a p85 regulatory subunit, of which there are three separate genes (PIK3R1, PIK3R2 and PIK3R3). This heterodimerisation keeps the p85/p110 complex in an inactive state, which can be relieved by p 85 binding to cell surface receptors.

This perspective focuses on PIK3CA, the class I PI3K that is most frequently mutationally-activated and/or gene-amplified in solid tumours (Figure 1B). In haematological malignancies, PIK3CA mutation or amplification is extremely rare $(<0.1 \%$ in lymphoid and myeloid malignancies; cBioportal, accessed June 2019), with a slightly higher frequency of these events in PIK3CD (1\% in lymphoid and myeloid malignancies; cBioportal, accessed June 2019), which is almost exclusively constituted by mutations in PIK3CD in diffuse large B-cell lymphoma. No consistent overexpression of class I PI3K subunits has been observed in haematological malignancies.

Common 'oncogenic' hotspots of PIK3CA mutations are found in the helical (E542K, E545K) and C-terminal domains (H1047R) of p110 $\alpha$ [7]. Oncogenic mutations in PIK3CA lead to a constitutive de-inhibition of the $\mathrm{p} 110 \alpha / \mathrm{p} 85$ complex [8]. Such de-inhibition of the p85/p110 complex can also be achieved by mutations in the genes encoding the $\mathrm{p} 85$ subunits [9].

The non-mutated, wild-type PIK3CA gene is also frequently amplified in cancer, such as in lung squamous carcinoma where this occurs as part of amplification of the $3 q$ genomic locus, the most common genomic aberration in this cancer [10]. It is currently unclear whether amplification of $P I K 3 C A$ on its own leads to enhanced signalling. Whereas expression of oncogenically-mutated PIK3CA in cell-based studies leads to PI3K pathway activation (as assessed by phosphorylation of Akt/PKB), this is most often not the case upon overexpression of wild-type PIK3CA (see, for example, [11,12]). Overexpression of wild-type PIK3CA did not transform chicken embryo fibroblasts, in contrast to oncogenically mutated PIK3CA [13]. It is therefore possible that additional alterations in the pathway are required in order for PIK3CA amplification to result in PI3K pathway activation. In this context, recent data in squamous lung cancer show that PIK3CA amplification frequently co-occurs with amplification of Akt2 on chromosome 19 [14]. Evidence for a possible dosage dependency of genetic PI3K pathway activation in cancer, including for PIK3CA mutation [15,16], has recently re-emerged [4]. 
This is in line with other studies showing pervasive selection in cancer for oncogenic mutant allele imbalance $[17,18]$.

In the text below, we will refer to PIK3CA mutation or amplification as 'PIK3CA activation'.

\subsection{Chromosomal Instability, Whole-Genome Doubling and Aneuploidy-A Cellular Stress}

\subsubsection{Chromosomal Instability (CIN)}

Chromosomal Instability (CIN) is the dynamic process of chromosomal alterations occurring at an elevated rate, in the form of structural or numerical changes. Numerical CIN has been attributed to mitotic defects such as erroneous kinetochore-microtubule attachments, compromised centromere geometry, supernumerary centrosomes, impaired spindle assembly checkpoint, and sister chromatid cohesion [19]. Structural CIN has been linked to pre-mitotic processes such as replication stress, failures in DNA repair and defective telomere maintenance. It is manifested by the presence of duplicated, deleted or rearranged chromosome fragments, acentric fragments (centromere absent), dicentric chromosomes (two centromeres) and chromatin bridges, all of which compromise genomic integrity. The investigation of the possible links between pre-mitotic and mitotic defects is an active area of research $[20,21]$. Importantly, oncogenic activation of several signalling pathways has been shown to contribute to the induction of CIN by compromising the above cellular processes [22]. CIN is thought to allow cancer cells to adapt to selective pressures during tumour evolution, metastasis and treatment $[23,24]$, due to simultaneous dosage changes in a large number of genes.

\subsubsection{Whole Genome Doubling (WGD)}

Whole Genome Doubling (WGD), the duplication of the entire chromosome complement, is prevalent in cancer and a significant proportion of human tumours (over $50 \%$ for breast and lung) undergo WGD during development $[25,26]$. Mechanisms implicated in WGD include cytokinesis failure at the end of mitosis, endoreduplication and cell fusion [27]. In most cases, tetraploid cells are genomically unstable and accumulate numerical and/or structural chromosomal abnormalities, which can contribute to tumour heterogeneity and evolution. A stochastic model, based on the potency and chromosomal distribution of oncogenes and tumour suppressor genes, suggested that WGD represents a path to a commonly observed near-triploid state [28]. Recent analyses have provided strong evidence that WGD provides a buffering effect in cancer cells against the effects of gene or chromosome losses or deleterious mutations [29].

\subsubsection{Aneuploidy, Cellular Stress and the CIN Paradox}

Aneuploidy, referring to an abnormal number of chromosomes in a cell, imposes cellular stress due to imbalanced gene expression and increased burden on protein turnover machinery. This can lead to impaired proliferation [30-35] and can also induce cell death or senescence, often dependent on the level of CIN [36-38]. Studies in yeast suggest that perturbation of the stoichiometries of protein complexes, caused by the presence/absence of additional chromosomes, contributes to the so-called proteotoxic stress response $[39,40]$. Mammalian cells with an abnormal karyotype have been shown to activate the process of autophagy and lysosome-mediated protein degradation, possibly to cope with this stress [34,35]. Aneuploid yeast and human cancer cells also exhibit a sustained hypo-osmotic-like response, characterised by plasma membrane stress and impaired endocytosis, with an ensuing remodelling of cellular metabolism and a dependency on ubiquitin-mediated endocytic recycling of nutrient transporters [40].

It is not clear whether autophagy is a consequence or a cause of chromosomal aberrations. Autophagy has been implicated in preventing chromosomal instability and associated tumourigenesis, with impaired autophagy-promoting gene amplification, chromosome instability and aneuploidy [41]. A recent study suggested that autophagy is responsible for the cell death occurring at replicative 
crisis [42], underlining a tumour-suppressive role for autophagy at an early stage of immortalisation and malignant transformation.

It has now also become clear that the rate of chromosome segregation errors occurring in cancer cells must be within a sustainable range to avoid cell death associated with extreme karyotypic changes [31,32]. This helps to explain the so-called CIN/aneuploidy paradox [31], whereby extreme CIN is tumour-suppressive. Aneuploidy is thus not cancer-promoting per se, and low levels of $\mathrm{CIN}$ are now viewed as more biologically relevant for driving tumour-evolution and adaptation. Of note, deregulation of the tumour suppressor TP53, including through loss of TP53 expression or gain-of-function mutations in TP53, is a well-known tolerance mechanism towards aneuploidy [43-46].

\subsection{Microtubules and the Mitotic Spindle}

Microtubules are protein structures composed of $\alpha / \beta$-tubulin heterodimers in a head-to-tail arrangement. They nucleate from centrosomes (see Section 1.4 below) and are involved in many cellular processes such as mitosis, intracellular transport and cell motility [47-49]. Microtubules are polarised structures with a fast-growing, highly-dynamic plus-end (the main site of elongation) and a minus-end, which is slow growing, stable and often anchored at the centrosome. Microtubules are characterised by dynamic instability, undergoing cycles of growth and shrinkage, and are regulated by a broad range of stabilising and destabilising factors [47-49].

Chromosome segregation requires that chromosomes form attachments to the plus-ends of parallel microtubule bundles via kinetochores (Figure 2A). These are large multimeric protein complexes associated with the centromere of chromosomes that regulate the dynamics of the associated microtubules and power chromosome motion. The microtubule-kinetochore interface is highly dynamic, with microtubules growing and shrinking at the site of attachment. The correct attachment of sister kinetochores to microtubules emanating from opposite centrosomes is essential for the fidelity of chromosome segregation. Increased microtubule stability and defects in correction mechanisms of erroneous microtubule-kinetochore attachments lead to chromosome mis-segregation during cell division $[23,50]$. Altered microtubule assembly rates within mitotic spindles also impact CIN in cancer cells [51].

A.

\section{Wild-type cells}
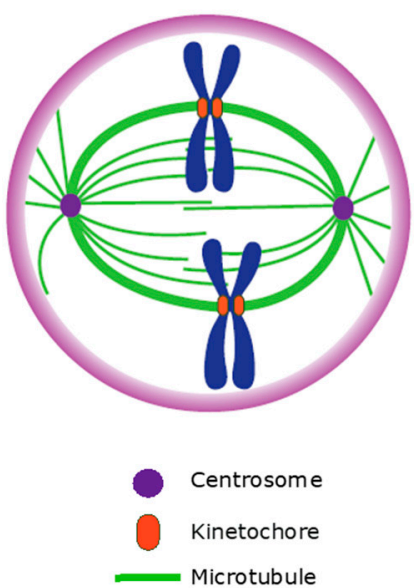

\section{B. Cells with} PIK3CA mutation/amplification

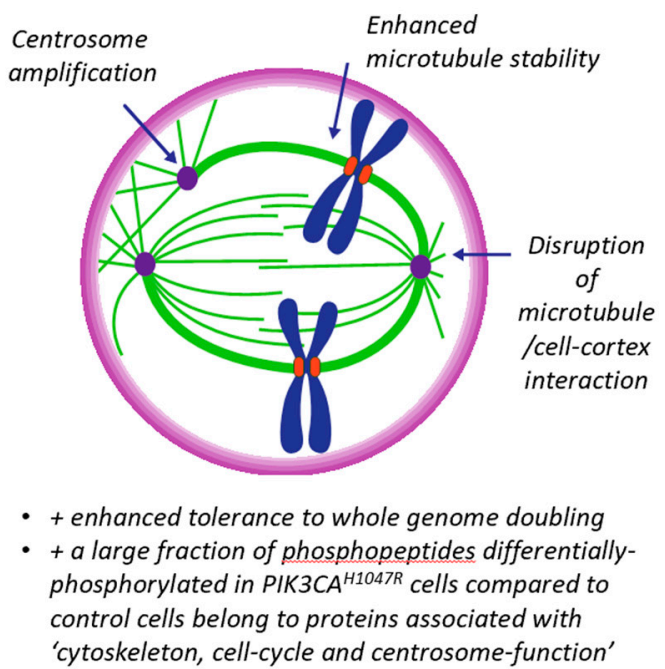

Figure 2. Schematic depicting the mitotic spindle in wild-type cells (A) and how this is deregulated in cells with PIK3CA mutation/amplification (B). 


\subsection{Centrosomes}

In proliferating cells, two complex microtubule structures called centrioles, embedded within a matrix of proteins known as the pericentriolar material (PCM), form the centrosome, which functions as the main microtubule-organising centre (MTOC). In many non-proliferating cells, centrioles migrate to the cell surface to template the assembly of a cilium.

A cell normally has one centrosome, which is duplicated once per cell cycle. Aberrant cellular centrosome numbers are associated with aneuploidy, CIN and cancer [52-54]. While multipolar divisions and the resulting aneuploidy often lead to non-viable progeny [55-58], many cells with supernumerary centrosomes either cluster them into two spindle poles, or selectively inactivate extra centrosomes to enable bipolar divisions [59-61]. Centrosome clustering efficiency depends on the cell type. For example, epithelial cells have low clustering efficiency and do not tolerate extra centrosomes [62]. E-cadherin loss leads to increased cortical contractility, which is sufficient to promote centrosome clustering, facilitating the proliferation and survival of cancer cells with extra centrosomes [62]. Importantly, supernumerary centrosomes and multipolar spindle geometry increase the probability of creating merotelic attachments (a single kinetochore attached to two spindle poles), which is a major mechanism of aneuploidy and chromosomal instability in cancer cells $[57,63,64]$.

Recent findings have reinforced the importance of centrosome amplification in cancer initiation [64-67]. It is important to mention, however, that there are several human conditions with rampant centrosome amplification, for example, due to mutations in centrosomal genes leading to microcephaly, dwarfism and ciliopathies, all of which are without a discernible increase in cancer (see, for example, [68]; reviewed in [69-71]).

In addition to their function as a MTOC, centrosomes have also been postulated to act as signalling hubs that integrate and coordinate a range of signalling pathways. This hypothesis is based on the observation that many signalling components, including kinases and phosphatases, have been associated with centrosomes and spindle poles [72-74] (see also Table 1; Table 2).

Table 1. PI3K pathway components found in centrosome/primary cilium.

\begin{tabular}{ccc}
\hline PI3K Pathway Component & References & Additional Information \\
\hline p85 regulatory subunit of PI3K & {$[75,76]$} & $\begin{array}{c}\text { p85 can associate with the centrosome in an } \\
\text { insulin-dependent manner }\end{array}$ \\
\cline { 2 - 3 } Akt/PKB & {$[77]$} & $\begin{array}{c}\text { Akt/PKB is phosphorylated during mitosis and is } \\
\text { present in the centrosome }\end{array}$ \\
\cline { 2 - 3 } & {$[78]$} & $\begin{array}{c}\text { T308-phosphorylated Akt/PKB is present in basal } \\
\text { body of primary cilia }\end{array}$ \\
& {$[79]$} & $\begin{array}{c}\text { S473-phosphorylated Akt/PKB is present in basal } \\
\text { body of primary cilia. Akt/PKB interacts with and } \\
\text { phosphorylates the ciliary protein Inversin. }\end{array}$ \\
\hline $\begin{array}{c}\text { TSC1/TSC2 (TSC2 is an } \\
\text { Akt/PKB substrate) }\end{array}$ & $\begin{array}{c}\text { Akt/PKB-inhibition prevents recruitment of PTEN to } \\
\text { mitotic centrosomes }\end{array}$ \\
\hline GSK3 (Akt/PKB substrate) & {$[81]$} & $\begin{array}{c}\text { TSC1 is present in centrosome. Phosphorylated TSC1 } \\
\text { and phosphorylated TSC2 co-immunoprecipitate } \\
\text { with Plk1 }\end{array}$ \\
\hline PTEN & {$[82]$} & $\begin{array}{c}\text { Phospho-GSK-3 at the centrosomes upon entry } \\
\text { into mitosis }\end{array}$ \\
\hline
\end{tabular}


Table 2. Akt/PKB substrates found in centrosome/primary cilium.

\begin{tabular}{|c|c|c|}
\hline Akt/PKB Substrate & References & Additional Information \\
\hline $\begin{array}{l}\text { TSC1/TSC2 (TSC2 is an } \\
\text { Akt/PKB substrate) }\end{array}$ & [81] & $\begin{array}{l}\text { TSC1 is present in centrosome. Phosphorylated TSC1 and } \\
\text { phosphorylated TSC } 2 \text { co-immunoprecipitate with Plk1 }\end{array}$ \\
\hline GSK3 $\beta$ & [77] & Phospho-GSK3 at the centrosomes upon entry into mitosis \\
\hline Inversin & [79] & $\begin{array}{c}\text { Akt/PKB interacts with and phosphorylates the ciliary } \\
\text { protein Inversin-dimerisation. Co-localisation of Inversin } \\
\text { and phosphorylated-Akt/PKB at the basal body is } \\
\text { augmented by PDGF-AA. }\end{array}$ \\
\hline TEIF & [83] & TIEF is a potential centrosome component \\
\hline Girdin & {$[84,85]$} & Girdin may localise to centrosomes \\
\hline
\end{tabular}

\section{PI3K Pathway Activation and CIN/WGD}

\subsection{PIK3CA/Akt}

Several oncogenic signalling pathways ranging from Ras and Raf [86-92] to Rb, Notch and many others have been shown to contribute to the induction of CIN (reviewed in [22]). We here propose a new potential CIN-inducing pathway, mediated by PIK3CA-AKT, which may also include downstream MTOR signalling.

We recently reported that expression of the PIK3CA ${ }^{\mathrm{H} 1047 \mathrm{R}}$ mutant can lead to centrosome amplification (in mouse embryonic fibroblasts (MEFs), the MCF10A immortalised breast cell line and in mouse tissues) and increased in vitro tolerance to WGD (in MEFs) [93], indicating that PI3K activation might be involved in CIN (Figure 2B). Signalling pathways involved in PIK3C $A^{\mathrm{H} 1047 \mathrm{R}}$-driven centrosome amplification include AKT, ROCK and CDK2/Cyclin E-nucleophosmin [93]. Overexpression of Akt/PKB has been shown to induce supernumerary centrosomes/aneuploidy in cell lines [94,95]. There is also some preliminary evidence in HeLa cells suggesting that mTOR hyperactivation may induce polyploidy [96].

It is of interest to note that $\sim 30 \%$ of the phosphopeptides differentially-phosphorylated in PIK3CA ${ }^{\mathrm{H} 1047 \mathrm{R}}$ MEFs compared to control cells belong to proteins associated with 'cytoskeleton, cell-cycle and centrosome function' [97]. In addition, expression of a gene set that controls mitosis (microtubule and mitotic spindle regulators) was found to be enriched in PIK3CA ${ }^{H 1047 R}$ MCF10A breast cancer cells [98]. Interestingly, this gene set was not enriched in MCF10A cells that had lost PTEN [98]. A study mapping the dynamic protein-protein interaction network within the core insulin signalling pathway in Drosophila also found significant enrichment for proteins involved in 'centrosome duplication' following 10 and $30 \mathrm{~min}$ of insulin stimulation [99].

Indirect evidence for a role for PI3K in centrosome biology was previously found in human HeLa and HCT116 cell lines, in which stable transfection of an oncogenic c-Met tyrosine kinase receptor induced centrosome amplification in a PI3K-dependent manner, independent of the MAPK pathway [100]. At the time, it was unclear whether these observations were artefacts of cell-based overexpression studies. Our demonstration that physiological induction of PIK3C $A^{\mathrm{H} 1047 \mathrm{R}}$ (i.e., in the heterozygous state and expressed from the endogenous promotor) can induce centrosome amplification and aneuploidy [93] more firmly establishes this biological role of mutant PI3K. In fact, PI3K also controls tetraploidisation under physiological conditions: in rodents, modulation of insulin concentration, and consequently Akt/PKB activity, orients hepatocytes into a specific cell-cycle program, leading to the generation of binucleated tetraploid cells [101].

PIK3CA mutation is very common in breast cancer, where it appears to be an early, clonal event [93]. Moreover, in genome-doubled breast cancers, the majority of PIK3CA mutations precede the genome duplication event, with PIK3CA mutations showing a tendency to be mutually exclusive with mutations in TP53 [93], a known tolerance mechanism towards genome doubling [43-45]. These data indicate a 
potential role of PIK3CA mutation as a tolerance mechanism for genome doubling in breast cancer, independent of the p53 pathway. Additional studies are required to determine whether oncogenic PIK3CA activation might function as a CIN inducer, as tolerance mechanism to CIN induced by other stimuli, or both.

\subsection{PTEN}

PTEN loss has been extensively linked to CIN, a biological role that is largely dependent on the scaffolding rather than the phosphatase function of PTEN [102], and therefore mostly independent of PI3K/Akt activity. Given that these PTEN effects can therefore not be modulated by pharmacological intervention targeting PI3K, these will not be described here. For an excellent review on the functions of PTEN in the maintenance of genome integrity, the reader is referred to [102].

\section{Potential Molecular Mechanisms Underlying PIK3CA-Related CIN}

It is possible that genetic PIK3CA-activation, due to its constitutive signalling (as opposed to transient PI3K signalling upon growth factor stimulation), leads to a deregulation of cell biological processes in such a way that these become cancer-promoting.

\subsection{Cell-Cycle Block by Constitutive PI3K (Over) Activation?}

PI3K/Akt signalling regulates the activity and expression of several key proteins involved in cell-cycle progression, including cyclin D and the cyclin-dependent kinase inhibitor proteins p21 and p27 (reviewed in [103-105]). PI3K activity oscillates during the cell cycle [106-109] suggesting that pathway signalling dynamics may be important for phenotypic regulation. Consistent with this notion, forced expression of constitutive PI3K $\alpha$ alleles blocks efficient cell-cycle progression [110,111], which can even lead to cell death under serum-free conditions [110]. A study using single-cell analysis provided further evidence that high PI3K activity cannot be sustained, with cells exhibiting high Akt activation in the cell population undergoing senescence [112]. Mechanisms implicated in a PI3K-driven cell-cycle block include a lack of downregulation of the cyclin E-Cdk2 complex, which normally disappears after entry into $S$ phase of the cell cycle [110], and an inability to increase the activity of the transcription factor FOXO1 downstream of Akt, which is necessary for cell-cycle completion [111]. The complexity of PI3K signalling dynamics is, however, poorly captured by conventional studies of the pathway. This has spurred the development of computational models, with a recent Boolean model predicting the mechanistic basis for cellular PI3K pathway oscillations as well as their impact on cytokinesis and cell death [113].

In the studies mentioned above [110-112], the long-term fate of cells undergoing cell-cycle blockade has not been investigated. Should these cells manage to exit this cell-cycle block, this might involve cytokinesis defects and chromosomal segregation errors, amongst others. Even if this occurred at low frequency in a cell population, if it were to take place continuously, this process could give rise to cell clones with altered genetic constellations. These cells could then seed or maintain cancer development, akin to the ability of drug-tolerant persister cells-a small fraction of the bulk cancer cell population - to serve as a latent reservoir of cells for treatment-resistant tumour growth $[114,115]$.

At present, it is not clear whether the observed defects in cell-cycle progression are an artefact of forced overexpression of supra-physiologically active PI3K constructs, or whether this would also occur upon endogenous oncogenic PIK3CA activation. In this regard, we did not find evidence for cell-cycle blockade in MEFs expressing an endogenous heterozygous PIK3C $A^{\mathrm{H} 1047 \mathrm{R}}$ allele [93]. Oncogenic activation of PI3K signaling has also been shown to elicit senescence in some cellular contexts $[112,116,117]$ but not in others $[93,118]$. Other than being context-dependent, evidence has been presented that PIK3CA activation is a weaker inducer of senescence than oncogenic Ras [119].

However, there is increasing evidence that genetic PI3K pathway activation in cancer might be a graded event, similar to observations of oncogenic K-Ras [18], with the presence of more than one mutant copy of PIK3CA and/or genetic activation of other PI3K pathway components seen in 
established tumours [4]. It is tempting to speculate that cell-cycle aberrations and possibly CIN might be induced beyond a certain threshold of sustained high PI3K pathway activation. In other words, in addition to disruption of the duration of PI3K pathway activation, the strength of the signal might also be of importance in the context of CIN.

\subsection{Impact of PI3K on Microtubules and the Mitotic Spindle}

Growth factor-stimulated PI3K activation [120] or oncogenic PIK3CA activation [121] have been shown to lead to microtubule stabilisation, a phenomenon that when sustained, can compromise genome integrity. Indeed, stabilisation of kinetochore-microtubule attachments at prometaphase or metaphase, by depletion of the kinesin-13 microtubule depolymerases Kif2b or MCAK, prevents the release of misoriented microtubule attachments, leading to merotelic attachments and other segregation effects [50].

Molecularly, the CLASP microtubule-associated proteins have been shown to colocalise at microtubule plus-ends in a PI3K/GSK3 $\beta$-dependent manner, resulting in microtubule stabilisation at the leading edge of motile fibroblasts [122]. Stathmin, a microtubule-destabilising protein whose activity is known to be reduced by phosphorylation on Ser-38 [123], is also of potential relevance in this context. Indeed, high phospho-Ser38-Stathmin is associated with PI3K pathway activation in aggressive endometrial cancer [124], with PI3K pathway inhibitors dampening Ser38 phosphorylation [125].

GSK3 $\beta$ is a kinase of potential relevance to the regulation of microtubule stabilisation by PI3K. This Ser/Thr kinase is constitutively-active in cells, but becomes inactivated upon phosphorylation by Akt [126]. In addition to its role in metabolic/insulin signalling, GSK3 $\beta$ is involved in microtubule regulation, such as through the phosphorylation of MAPs (MT-associated proteins), APC (anaphase-promoting complex) and CLASPs and, when active, generally decreases microtubule stability. It is possible that sustained GSK3 inactivation, due to constitutive PI3K/Akt activity upon PIK3CA activation, contributes to microtubule stabilisation. Although early work linked GSK3 $\beta$ and microtubules upon transient PI3K/Akt stimulation by growth factors $[77,127,128]$, GSK3 $\beta$ has since been largely ignored in the PI3K field.

$\mathrm{PIP}_{3}$ has been shown to be generated at the midcortex in metaphase cells and to be involved in spindle orientation [129-131]. The Carrera group further showed an involvement of p110 $\alpha$ in these phenomena, with $\mathrm{p} 110 \alpha$ becoming activated at mitosis entry and regulating early mitotic events, such as $\mathrm{PIP}_{3}$ generation, prometaphase progression and spindle orientation [131]. The latter could involve the regulation of cortical microtubule attachment complexes by p $110 \alpha$ (Figure 2B). Indeed, in HeLa cells, inhibition of $\mathrm{p} 110 \alpha$ dampens cortical clustering of LL5 $\beta$, a microtubule-anchoring protein [132] that attaches EB1/CLASP-bound microtubule plus-ends to the cell cortex [133]. LL5 $\beta$ contains a $\mathrm{PIP}_{3}$-binding $\mathrm{PH}$ domain and is thus a putative downstream effector of p110 $\alpha$. Upon PI3K activation, LL5 $\beta$ in complex with CLASP relocalises to the plasma membrane and orientates stabilised microtubules towards the leading edge [133].

Of note, cytoplasmic PTEN has also been reported to be mainly associated with microtubules, which may be important in regulating its function [134].

It is worth pointing out the existence of conflicting data on the impact of PI3K-pathway mutation on cellular sensitivity to microtubule-deregulating anti-mitotic drugs (on their own or in combination with PI3K inhibitors) [11,120,135]. Many studies used early generation pan-PI3K/mTOR inhibitors and cancer cell lines with complex genetic backgrounds, precluding a clear interpretation of the observations made. In addition, several studies have used the PI3K inhibitor BKM120/Buparlisib, which directly binds to microtubules and interferes with microtubule polymerisation [136,137].

\subsection{Impact of PI3K on Centrosomes (and Vice Versa)}

Recent data have implicated PI3K activation in centrosome amplification, such as by PIK3CA ${ }^{\mathrm{H} 1407 \mathrm{R}}$ activation in MEFs [93]. Centrosome amplification induced by the oncogenic c-Met-tyrosine kinase receptor has been shown to occur via PI3K/Akt, independent of the MAPK pathway [100]. 
Moreover, EGF controls centrosome separation through Akt, independent of MEK, MAPK or mTORC1 pathways [138].

PIK3CA activation is known to promote a mesenchymal morphology in a range of epithelial cell lines [117,139]. Given that epithelial cells are innately inefficient at centrosome clustering [62], such PIK3CA-induced epithelial-to-mesenchymal transition and altered cortical tension may enable these cells to efficiently cluster supernumerary centrosomes [62] and divide in the wake of misaligned chromosomes, pre-disposing them to CIN. On the other hand, persistent proliferation of cells undergoing epithelial-to-mesenchymal transition has been shown to lead to genomic instability [140].

Interestingly, several PI3K pathway components (Table 1) and substrates for the PI3K-activated kinase Akt/PKB (Table 2) can be found in centrosomes. Members of the transforming acidic coiled-coil (TACC) family of proteins, implicated in centrosome regulation and cancer, are of particular interest in this context [141,142]. Indeed, TACC1, a centrosome-localised microtubule-binding protein, was recently identified as a top hit in a genome-wide shRNA screen for genes that convert PI3K inhibitor-induced cytostasis to cytotoxicity, selectively in PIK3CA-mutant cells [143]. This is in line with data indicating that TACC1 overexpression protects cells from cytostasis induced by PI3K inhibition [144]. This differential sensitivity may relate to a vulnerability generated by microtubule/centrosome changes in PIK3CA-mutant cells. Moreover, the TACC3 isoform interacts with TSC2 [145], a bona fide Akt substrate, suggesting a possible interplay between PI3K/Akt and TACC/centrosome pathways. FGFR-TACC fusion proteins, generated by gene translocations in cancer, have also been shown to display oncogenic activity, to induce chromosomal segregation defects and to trigger aneuploidy [146].

Several other studies support a reciprocal relationship between the PI3K pathway and centrosomal regulation. An RNAi screen in Drosophila thus identified proteins involved in the centrosome cycle as regulators of acute insulin-dependent AKT activation [99]. Microtubule acetylation has also recently been linked to sequestration and inhibition of AKT [147]. Further understanding of this intricate crosstalk is required to determine how it may influence or be influenced by oncogenic PIK3CA-induced centrosome amplification.

\section{Potential Therapeutic Exploitation in Cancer Prevention and Dampening of Tumour Evolution}

At present, there are no therapies aiming to interfere with tumour evolution [23]. As argued above, it is possible that the generation and/or tolerance of CIN is a cancer-promoting activity of oncogenic PI3K activation, resulting in irreversible genetic alterations and greater ability to adapt to selective pressures, due to clonal diversification [23]. This potentially pre-disposes cells to aneuploidy, setting the scene for cooperation with other cancer-promoting genetic lesions and fostering cell-to-cell variation, the substrate for tumour evolution. This would potentially allow PIK3CA activation to act as a continuous driver/facilitator of genetic changes in cancer, but also offer a druggable opportunity to interfere with tumour evolution. An important question is which cancers would potentially benefit from interfering with PI3K activity to block CIN, and whether such an approach would require the maximum-tolerated doses of PI3K inhibitors that are currently used in the clinic.

With regards to the first question, it is of relevance to note that mutation of PIK3CA is an early clonal event, occurring before WGD, in both breast cancer [93] and in colon cancer [148]. This is also the case for PIK3CA amplification (as part of a 3q arm amplification) in lung squamous cell carcinoma [149]. In some cases of colon cancer, PIK3CA mutation was estimated to have occurred at least a decade before cancer diagnosis [148]. Especially upon early diagnosis of the presence of such genetic alterations, for example, using liquid biopsies that can detect PIK3CA mutation [150], it is tempting to speculate that administration of low doses of PI3K pathway inhibitors could be used as a strategy to prevent cancer development and/or progression [151].

In other cancer types where PI3K pathway activation is not clonal such as in renal cell carcinoma, evidence indicates that the PI3K-AKT-mTORC1 pathway often becomes recurrently activated at multiple branch points during tumour evolution [152]. This occurs in separate subclones within the 
same tumour [152] and is an example of so-called parallel tumour evolution that converges upon PI3K activation [153]. In these cancers, interference with PI3K signalling as part of a maintenance therapy might also dampen tumour evolution.

With regards to the question of drug dose, it would be challenging to administer high doses of PI3K inhibitors in a preventative or maintenance setting, due to toxic side effects and cost. Moreover, high doses of PI3K inhibitors aiming to wipe out all cellular PI3K activity often give rise to feedback PI3K re-/over-activation, which would clearly be undesirable in this context. Although this remains to be proven, it is possible that oncogenic PIK3CA leads to low-level PI3K signalling, compared to growth-factor-stimulated PI3K activation. This would mean that low doses of PI3K inhibitors might allow the specific dampening of oncogenic PI3K signalling while still allowing normal PI3K signalling, and thereby interfere with tumour evolution. The feasibility of such low-dose PI3K inhibitor treatment is supported by observations in patients with so-called PIK3CA-related overgrowth syndrome (PROS), caused by embryonic acquisition of mosaic activating PIK3CA mutations [154]. In this context, long-term administration of low doses of a PI3K $\alpha$-selective inhibitor have led to dramatic improvements in disease severity with negligible or no side effects [155], with some patients having been on a low dose PI3K $\alpha$ inhibitor for up to 3.5 years (Guillaume Canaud, personal communication).

It is important to emphasise that administration of such a low dose of a PI3K inhibitor is not expected to induce anti-proliferation or cancer regression in advanced cancers, which would require standard anti-cancer therapies such as chemotherapy or surgery.

\section{Concluding Remarks}

In this perspective, we have summarised the evidence for a potential role of PIK3CA activation in the induction and/or tolerance of CIN. Such a role could be indirect; for example, by providing survival signals to cope with the cell stress imposed by CIN. A role in CIN could also derive from the sustained pathway stimulation by PIK3CA activation (which might disrupt cellular processes that normally require cyclical regulation such as cell-cycle progression) and/or the dose level of PI3K pathway activation.

A clear role of PIK3CA in CIN may not have been uncovered to date because PI3K research has mainly focused on the analysis of bulk cell populations, using either PI3K inhibitors, experimental conditions of acute signalling often by supra-physiological doses of growth factors, and established PIK3CA mutant cells that have adapted to constitutive PI3K activation. It is clear that single cell analyses will be critical to capture possible CIN and cell heterogeneity induced by PIK3CA activation, in addition to appropriate cell- and tissue-based models such as 2D/3D cultures [156] and inducible models of PIK3CA activation. Bioinformatic analysis of human tumours may also allow the correlation of the timing of PIK3CA activation with CIN in whole tissues. Together, such data could underpin the potential exploitation of this knowledge in cancer prevention, or dampening cancer progression using PI3K pathway inhibitors. Given that other growth-factor-related oncogenes such as Ras and Raf might also regulate CIN [86-92], one could even speculate that a cocktail of oncogene pathway inhibitors, given at low doses, might be an effective way to dampen cancer evolution (reviewed in [151]).

Funding: R.R.M. is funded by the Wellcome Trust (210752; to Prof. Robert Semple, University of Edinburgh). K.L.D. is funded by a Cancer Research UK studentship (C416/A25196). E.L. is funded by the Ong Hin Tiang \& Ong Sek Pek Foundation, Malaysia. Work in the E.V. laboratory is funded by the Cancer Research UK Lung Cancer Centre of Excellence (C7893/A24956), the Biotechnology and Biological Sciences Research Council (BB/P027067/1) and Cancer Research UK (C23338/A25722). The B.V. laboratory is supported by PTEN Research, Cancer Research UK (C23338/A25722) and the UK NIHR University College London Hospitals Biomedical Research Centre.

Acknowledgments: We thank Lizzy Foxall and Alex Sullivan for critical reading of the manuscript and Robert Semple (University of Edinburgh) for critical reading of the manuscript and for support to R.R.M.

Conflicts of Interest: B.V. is a consultant for Karus Therapeutics (Oxford, UK), iOnctura (Geneva, Switzerland) and Venthera (Palo Alto, US) and has received speaker fees from Gilead Sciences (Foster City, US). The other authors have no potential conflicts of interest to report. 


\section{References}

1. Bilanges, B.; Posor, Y.; Vanhaesebroeck, B. Pi3k isoforms in cell signalling and vesicle trafficking. Nat. Rev. Mol. Cell Biol. 2019. [CrossRef] [PubMed]

2. Fruman, D.A.; Chiu, H.; Hopkins, B.D.; Bagrodia, S.; Cantley, L.C.; Abraham, R.T. The pi3k pathway in human disease. Cell 2017, 170, 605-635. [CrossRef] [PubMed]

3. Lee, Y.R.; Chen, M.; Pandolfi, P.P. The functions and regulation of the pten tumour suppressor: New modes and prospects. Nat. Rev. Mol. Cell Biol. 2018, 19, 547-562. [CrossRef] [PubMed]

4. Madsen, R.R.; Knox, R.G.; Pearce, W.; Lopez, S.; Mahler-Araujo, B.; McGranahan, N.; Vanhaesebroeck, B.; Semple, R.K. Oncogenic pik3ca promotes cellular stemness in an allele dose-dependent manner. Proc. Natl. Acad. Sci. USA 2019, 116, 8380-8389. [CrossRef] [PubMed]

5. Gao, J.; Aksoy, B.A.; Dogrusoz, U.; Dresdner, G.; Gross, B.; Sumer, S.O.; Sun, Y.; Jacobsen, A.; Sinha, R.; Larsson, E.; et al. Integrative analysis of complex cancer genomics and clinical profiles using the cbioportal. Sci. Signal. 2013, 6, pl1. [CrossRef] [PubMed]

6. Cerami, E.; Gao, J.; Dogrusoz, U.; Gross, B.E.; Sumer, S.O.; Aksoy, B.A.; Jacobsen, A.; Byrne, C.J.; Heuer, M.L.; Larsson, E.; et al. The cbio cancer genomics portal: An open platform for exploring multidimensional cancer genomics data. Cancer Discov. 2012, 2, 401-404. [CrossRef] [PubMed]

7. Arafeh, R.; Samuels, Y. Pik3ca in Cancer: The Past 30 Years. Semin Cancer Biol. 2019. [CrossRef] [PubMed]

8. Burke, J.E.; Perisic, O.; Masson, G.R.; Vadas, O.; Williams, R.L. Oncogenic mutations mimic and enhance dynamic events in the natural activation of phosphoinositide 3-kinase p110alpha (pik3ca). Proc. Natl. Acad. Sci. USA 2012, 109, 15259-15264. [CrossRef]

9. Burke, J.E. Structural basis for regulation of phosphoinositide kinases and their involvement in human disease. Mol. Cell 2018, 71, 653-673. [CrossRef]

10. Cancer Genome Atlas Research Network. Comprehensive genomic characterization defines human glioblastoma genes and core pathways. Nature 2008, 455, 1061-1068. [CrossRef] [PubMed]

11. Isakoff, S.J.; Engelman, J.A.; Irie, H.Y.; Luo, J.; Brachmann, S.M.; Pearline, R.V.; Cantley, L.C.; Brugge, J.S. Breast cancer-associated pik3ca mutations are oncogenic in mammary epithelial cells. Cancer Res. 2005, 65, 10992-11000. [CrossRef] [PubMed]

12. Hutti, J.E.; Pfefferle, A.D.; Russell, S.C.; Sircar, M.; Perou, C.M.; Baldwin, A.S. Oncogenic pi3k mutations lead to nf-kappab-dependent cytokine expression following growth factor deprivation. Cancer Res. 2012, 72, 3260-3269. [CrossRef] [PubMed]

13. Kang, S.; Denley, A.; Vanhaesebroeck, B.; Vogt, P.K. Oncogenic transformation induced by the p110beta, -gamma, and -delta isoforms of class i phosphoinositide 3-kinase. Proc. Natl. Acad. Sci. USA 2006, 103, 1289-1294. [CrossRef] [PubMed]

14. Teixeira, V.H.; Pipinikas, C.P.; Pennycuick, A.; Lee-Six, H.; Chandrasekharan, D.; Beane, J.; Morris, T.J.; Karpathakis, A.; Feber, A.; Breeze, C.E.; et al. Deciphering the genomic, epigenomic, and transcriptomic landscapes of pre-invasive lung cancer lesions. Nat. Med. 2019, 25, 517-525. [CrossRef] [PubMed]

15. Stemke-Hale, K.; Gonzalez-Angulo, A.M.; Lluch, A.; Neve, R.M.; Kuo, W.L.; Davies, M.; Carey, M.; Hu, Z.; Guan, Y.; Sahin, A.; et al. An integrative genomic and proteomic analysis of pik3ca, pten, and akt mutations in breast cancer. Cancer Res. 2008, 68, 6084-6091. [CrossRef] [PubMed]

16. Oda, K.; Okada, J.; Timmerman, L.; Rodriguez-Viciana, P.; Stokoe, D.; Shoji, K.; Taketani, Y.; Kuramoto, H.; Knight, Z.A.; Shokat, K.M.; et al. Pik3ca cooperates with other phosphatidylinositol 3'-kinase pathway mutations to effect oncogenic transformation. Cancer Res. 2008, 68, 8127-8136. [CrossRef] [PubMed]

17. Bielski, C.M.; Donoghue, M.T.A.; Gadiya, M.; Hanrahan, A.J.; Won, H.H.; Chang, M.T.; Jonsson, P.; Penson, A.V.; Gorelick, A.; Harris, C.; et al. Widespread selection for oncogenic mutant allele imbalance in cancer. Cancer Cell 2018, 34, 852-862. [CrossRef]

18. Mueller, S.; Engleitner, T.; Maresch, R.; Zukowska, M.; Lange, S.; Kaltenbacher, T.; Konukiewitz, B.; Ollinger, R.; Zwiebel, M.; Strong, A.; et al. Evolutionary routes and kras dosage define pancreatic cancer phenotypes. Nature 2018, 554, 62-68. [CrossRef]

19. Gordon, D.J.; Resio, B.; Pellman, D. Causes and consequences of aneuploidy in cancer. Nat. Rev. Genet. 2012, 13, 189-203. [CrossRef] 
20. Burrell, R.A.; McClelland, S.E.; Endesfelder, D.; Groth, P.; Weller, M.C.; Shaikh, N.; Domingo, E.; Kanu, N.; Dewhurst, S.M.; Gronroos, E.; et al. Replication stress links structural and numerical cancer chromosomal instability. Nature 2013, 494, 492-496. [CrossRef]

21. Zhang, C.Z.; Spektor, A.; Cornils, H.; Francis, J.M.; Jackson, E.K.; Liu, S.; Meyerson, M.; Pellman, D. Chromothripsis from DNA damage in micronuclei. Nature 2015, 522, 179-184. [CrossRef] [PubMed]

22. Orr, B.; Compton, D.A. A double-edged sword: How oncogenes and tumor suppressor genes can contribute to chromosomal instability. Front. Oncol. 2013, 3, 164. [CrossRef] [PubMed]

23. Sansregret, L.; Vanhaesebroeck, B.; Swanton, C. Determinants and clinical implications of chromosomal instability in cancer. Nat. Rev. Clin. Oncol. 2018, 15, 139-150. [CrossRef] [PubMed]

24. Bakhoum, S.F.; Cantley, L.C. The multifaceted role of chromosomal instability in cancer and its microenvironment. Cell 2018, 174, 1347-1360. [CrossRef] [PubMed]

25. Carter, S.L.; Cibulskis, K.; Helman, E.; McKenna, A.; Shen, H.; Zack, T.; Laird, P.W.; Onofrio, R.C.; Winckler, W.; Weir, B.A.; et al. Absolute quantification of somatic DNA alterations in human cancer. Nat. Biotechnol. 2012, 30, 413-421. [CrossRef] [PubMed]

26. Zack, T.I.; Schumacher, S.E.; Carter, S.L.; Cherniack, A.D.; Saksena, G.; Tabak, B.; Lawrence, M.S.; Zhsng, C.Z.; Wala, J.; Mermel, C.H.; et al. Pan-cancer patterns of somatic copy number alteration. Nat. Genet. 2013, 45, 1134-1140. [CrossRef] [PubMed]

27. Davoli, T.; de Lange, T. The causes and consequences of polyploidy in normal development and cancer. Annu. Rev. Cell Dev. Biol. 2011, 27, 585-610. [CrossRef] [PubMed]

28. Laughney, A.M.; Elizalde, S.; Genovese, G.; Bakhoum, S.F. Dynamics of tumor heterogeneity derived from clonal karyotypic evolution. Cell Rep. 2015, 12, 809-820. [CrossRef] [PubMed]

29. López, S.; Lim, E.; Huebner, A.; Dietzen, M.; Mourikis, T.; Watkins, T.B.K.; Rowan, A.; Dewhurst, S.M.; Birkbak, N.J.; Wilson, G.A.; et al. Whole genome doubling mitigates muller's ratchet in cancer evolution. bioRxiv 2019. [CrossRef]

30. Oromendia, A.B.; Amon, A. Aneuploidy: Implications for protein homeostasis and disease. Dis. Mod. Mech. 2014, 7, 15-20. [CrossRef]

31. Sheltzer, J.M.; Amon, A. The aneuploidy paradox: Costs and benefits of an incorrect karyotype. Trends Genet. 2011, 27, 446-453. [CrossRef] [PubMed]

32. Naylor, R.M.; van Deursen, J.M. Aneuploidy in cancer and aging. Annu. Rev. Genet. 2016, 50, 45-66. [CrossRef] [PubMed]

33. Santaguida, S.; Amon, A. Short- and long-term effects of chromosome mis-segregation and aneuploidy. Nat. Rev. Mol. Cell Biol. 2015, 16, 473-485. [CrossRef] [PubMed]

34. Stingele, S.; Stoehr, G.; Peplowska, K.; Cox, J.; Mann, M.; Storchova, Z. Global analysis of genome, transcriptome and proteome reveals the response to aneuploidy in human cells. Mol. Syst. Biol. 2012, 8, 608. [CrossRef] [PubMed]

35. Stingele, S.; Stoehr, G.; Storchova, Z. Activation of autophagy in cells with abnormal karyotype. Autophagy 2013, 9, 246-248. [CrossRef] [PubMed]

36. He, Q.; Au, B.; Kulkarni, M.; Shen, Y.; Lim, K.J.; Maimaiti, J.; Wong, C.K.; Luijten, M.N.H.; Chong, H.C.; Lim, E.H.; et al. Chromosomal instability-induced senescence potentiates cell non-autonomous tumourigenic effects. Oncogenesis 2018, 7, 62. [CrossRef] [PubMed]

37. Fulda, S.; Gorman, A.M.; Hori, O.; Samali, A. Cellular stress responses: Cell survival and cell death. Int. J. Cell Biol. 2010, 2010, 214074. [CrossRef] [PubMed]

38. Andriani, G.A.; Almeida, V.P.; Faggioli, F.; Mauro, M.; Tsai, W.L.; Santambrogio, L.; Maslov, A.; Gadina, M.; Campisi, J.; Vijg, J.; et al. Whole chromosome instability induces senescence and promotes sasp. Sci. Rep. 2016, 6, 35218. [CrossRef] [PubMed]

39. Oromendia, A.B.; Dodgson, S.E.; Amon, A. Aneuploidy causes proteotoxic stress in yeast. Genes Dev. 2012, 26, 2696-2708. [CrossRef] [PubMed]

40. Tsai, H.J.; Nelliat, A.R.; Choudhury, M.I.; Kucharavy, A.; Bradford, W.D.; Cook, M.E.; Kim, J.; Mair, D.B.; Sun, S.X.; Schatz, M.C.; et al. Hypo-osmotic-like stress underlies general cellular defects of aneuploidy. Nature 2019, 570, 117-121. [CrossRef] [PubMed]

41. Mathew, R.; Kongara, S.; Beaudoin, B.; Karp, C.M.; Bray, K.; Degenhardt, K.; Chen, G.; Jin, S.; White, E. Autophagy suppresses tumor progression by limiting chromosomal instability. Genes Dev. 2007, 21, 1367-1381. [CrossRef] [PubMed] 
42. Nassour, J.; Radford, R.; Correia, A.; Fuste, J.M.; Schoell, B.; Jauch, A.; Shaw, R.J.; Karlseder, J. Autophagic cell death restricts chromosomal instability during replicative crisis. Nature 2019, 565, 659-663. [CrossRef] [PubMed]

43. Aylon, Y.; Oren, M. P53: Guardian of ploidy. Mol. Oncol. 2011, 5, 315-323. [CrossRef] [PubMed]

44. Thompson, S.L.; Compton, D.A. Proliferation of aneuploid human cells is limited by a p53-dependent mechanism. J. Cell Biol. 2010, 188, 369-381. [CrossRef] [PubMed]

45. McGranahan, N.; Favero, F.; de Bruin, E.C.; Birkbak, N.J.; Szallasi, Z.; Swanton, C. Clonal status of actionable driver events and the timing of mutational processes in cancer evolution. Sci. Transl. Med. 2015, 7, 283 ra254. [CrossRef]

46. Hanel, W.; Moll, U.M. Links between mutant p53 and genomic instability. J. Cell. Biochem. 2012, 113, 433-439. [CrossRef] [PubMed]

47. Lansbergen, G.; Akhmanova, A. Microtubule plus end: A hub of cellular activities. Traffic 2006, 7, $499-507$. [CrossRef] [PubMed]

48. Lyle, K.; Kumar, P.; Wittmann, T. Snapshot: Microtubule regulators ii. Cell 2009, 136, 566. [CrossRef] [PubMed]

49. Lyle, K.; Kumar, P.; Wittmann, T. Snapshot: Microtubule regulators i. Cell 2009, 136, 380. [PubMed]

50. Bakhoum, S.F.; Thompson, S.L.; Manning, A.L.; Compton, D.A. Genome stability is ensured by temporal control of kinetochore-microtubule dynamics. Nat. Cell Biol. 2009, 11, 27-35. [CrossRef] [PubMed]

51. Ertych, N.; Stolz, A.; Stenzinger, A.; Weichert, W.; Kaulfuss, S.; Burfeind, P.; Aigner, A.; Wordeman, L.; Bastians, H. Increased microtubule assembly rates influence chromosomal instability in colorectal cancer cells. Nat. Cell Biol. 2014, 16, 779-791. [CrossRef] [PubMed]

52. Cosenza, M.R.; Kramer, A. Centrosome amplification, chromosomal instability and cancer: Mechanistic, clinical and therapeutic issues. Chromosome Res. 2016, 24, 105-126. [CrossRef] [PubMed]

53. Godinho, S.A.; Pellman, D. Causes and consequences of centrosome abnormalities in cancer. Philos. Trans. R. Soc. B Biol. Sci. 2014, 369, 20130467. [CrossRef] [PubMed]

54. Gonczy, P. Centrosomes and cancer: Revisiting a long-standing relationship. Nat. Rev. Cancer 2015, 15, 639-652. [CrossRef] [PubMed]

55. Kramer, A.; Maier, B.; Bartek, J. Centrosome clustering and chromosomal (in)stability: A matter of life and death. Mol. Oncol. 2011, 5, 324-335. [CrossRef] [PubMed]

56. Weaver, B.A.; Silk, A.D.; Montagna, C.; Verdier-Pinard, P.; Cleveland, D.W. Aneuploidy acts both oncogenically and as a tumor suppressor. Cancer Cell 2007, 11, 25-36. [CrossRef] [PubMed]

57. Ganem, N.J.; Godinho, S.A.; Pellman, D. A mechanism linking extra centrosomes to chromosomal instability. Nature 2009, 460, 278-282. [CrossRef]

58. Brinkley, B.R. Managing the centrosome numbers game: From chaos to stability in cancer cell division. Trends Cell Biol. 2001, 11, 18-21. [CrossRef]

59. Basto, R.; Brunk, K.; Vinadogrova, T.; Peel, N.; Franz, A.; Khodjakov, A.; Raff, J.W. Centrosome amplification can initiate tumorigenesis in flies. Cell 2008, 133, 1032-1042. [CrossRef]

60. Marthiens, V.; Piel, M.; Basto, R. Never tear us apart-the importance of centrosome clustering. J. Cell Sci. 2012, 125, 3281-3292. [CrossRef]

61. Sabino, D.; Gogendeau, D.; Gambarotto, D.; Nano, M.; Pennetier, C.; Dingli, F.; Arras, G.; Loew, D.; Basto, R. Moesin is a major regulator of centrosome behavior in epithelial cells with extra centrosomes. Curr. Biol. 2015, 25, 879-889. [CrossRef] [PubMed]

62. Rhys, A.D.; Monteiro, P.; Smith, C.; Vaghela, M.; Arnandis, T.; Kato, T.; Leitinger, B.; Sahai, E.; McAinsh, A.; Charras, G.; et al. Loss of e-cadherin provides tolerance to centrosome amplification in epithelial cancer cells. J. Cell Biol. 2018, 217, 195-209. [CrossRef] [PubMed]

63. Silkworth, W.T.; Nardi, I.K.; Scholl, L.M.; Cimini, D. Multipolar spindle pole coalescence is a major source of kinetochore mis-attachment and chromosome mis-segregation in cancer cells. PLoS ONE 2009, 4, e6564. [CrossRef] [PubMed]

64. Levine, M.S.; Bakker, B.; Boeckx, B.; Moyett, J.; Lu, J.; Vitre, B.; Spierings, D.C.; Lansdorp, P.M.; Cleveland, D.W.; Lambrechts, D.; et al. Centrosome amplification is sufficient to promote spontaneous tumorigenesis in mammals. Dev. Cell 2017, 40, 313-322. [CrossRef] [PubMed]

65. Raff, J.W.; Basto, R. Centrosome amplification and cancer: A question of sufficiency. Dev. Cell 2017, 40, 217-218. [CrossRef] [PubMed] 
66. Coelho, P.A.; Bury, L.; Shahbazi, M.N.; Liakath-Ali, K.; Tate, P.H.; Wormald, S.; Hindley, C.J.; Huch, M.; Archer, J.; Skarnes, W.C.; et al. Over-expression of plk4 induces centrosome amplification, loss of primary cilia and associated tissue hyperplasia in the mouse. Open Biol. 2015, 5, 150209. [CrossRef] [PubMed]

67. Sercin, O.; Larsimont, J.C.; Karambelas, A.E.; Marthiens, V.; Moers, V.; Boeckx, B.; Le Mercier, M.; Lambrechts, D.; Basto, R.; Blanpain, C. Transient plk4 overexpression accelerates tumorigenesis in p53-deficient epidermis. Nat. Cell Biol. 2016, 18, 100-110. [CrossRef]

68. Chen, J.H.; Segni, M.; Payne, F.; Huang-Doran, I.; Sleigh, A.; Adams, C.; Consortium, U.K.; Savage, D.B.; O'Rahilly, S.; Semple, R.K.; et al. Truncation of pocla associated with short stature and extreme insulin resistance. J. Mol. Endocrinol. 2015, 55, 147-158. [CrossRef]

69. Bettencourt-Dias, M.; Hildebrandt, F.; Pellman, D.; Woods, G.; Godinho, S.A. Centrosomes and cilia in human disease. Trends Genet. 2011, 27, 307-315. [CrossRef]

70. Chavali, P.L.; Putz, M.; Gergely, F. Small organelle, big responsibility: The role of centrosomes in development and disease. Philos. Trans. R. Soc. B Biol. Sci. 2014, 369, 20130468. [CrossRef]

71. Nigg, E.A.; Raff, J.W. Centrioles, centrosomes, and cilia in health and disease. Cell 2009, 139, 663-678. [CrossRef] [PubMed]

72. Arquint, C.; Gabryjonczyk, A.M.; Nigg, E.A. Centrosomes as signalling centres. Philos. Trans. R. Soc. B Biol. Sci. 2014, 369, 20130464. [CrossRef] [PubMed]

73. Lee, J.Y.; Hong, W.J.; Majeti, R.; Stearns, T. Centrosome-kinase fusions promote oncogenic signaling and disrupt centrosome function in myeloproliferative neoplasms. PLoS ONE 2014, 9, e92641. [CrossRef] [PubMed]

74. Chan, K.Y.; Alonso-Nunez, M.; Grallert, A.; Tanaka, K.; Connolly, Y.; Smith, D.L.; Hagan, I.M. Dialogue between centrosomal entrance and exit scaffold pathways regulates mitotic commitment. J. Cell Biol. 2017, 216, 2795-2812. [CrossRef] [PubMed]

75. Kapeller, R.; Chakrabarti, R.; Cantley, L.; Fay, F.; Corvera, S. Internalization of activated platelet-derived growth factor receptor-phosphatidylinositol-3' kinase complexes: Potential interactions with the microtubule cytoskeleton. Mol. Cell. Biol. 1993, 13, 6052-6063. [CrossRef] [PubMed]

76. Kapeller, R.; Toker, A.; Cantley, L.C.; Carpenter, C.L. Phosphoinositide 3-kinase binds constitutively to alpha/beta-tubulin and binds to gamma-tubulin in response to insulin. J. Biol. Chem. 1995, 270, 25985-25991. [CrossRef] [PubMed]

77. Wakefield, J.G.; Stephens, D.J.; Tavare, J.M. A role for glycogen synthase kinase-3 in mitotic spindle dynamics and chromosome alignment. J. Cell Sci. 2003, 116, 637-646. [CrossRef]

78. Zhu, D.; Shi, S.; Wang, H.; Liao, K. Growth arrest induces primary-cilium formation and sensitizes igf-1-receptor signaling during differentiation induction of 3t3-11 preadipocytes. J. Cell Sci. 2009, 122, 2760-2768. [CrossRef]

79. Suizu, F.; Hirata, N.; Kimura, K.; Edamura, T.; Tanaka, T.; Ishigaki, S.; Donia, T.; Noguchi, H.; Iwanaga, T.; Noguchi, M. Phosphorylation-dependent akt-inversin interaction at the basal body of primary cilia. EMBO J. 2016, 35, 1346-1363. [CrossRef]

80. Leonard, M.K.; Hill, N.T.; Bubulya, P.A.; Kadakia, M.P. The pten-akt pathway impacts the integrity and composition of mitotic centrosomes. Cell Cycle 2013, 12, 1406-1415. [CrossRef]

81. Astrinidis, A.; Senapedis, W.; Henske, E.P. Hamartin, the tuberous sclerosis complex 1 gene product, interacts with polo-like kinase 1 in a phosphorylation-dependent manner. Hum. Mol. Genet. 2006, 15, 287-297. [CrossRef] [PubMed]

82. van Ree, J.H.; Nam, H.J.; Jeganathan, K.B.; Kanakkanthara, A.; van Deursen, J.M. Pten regulates spindle pole movement through dlg1-mediated recruitment of eg5 to centrosomes. Nat. Cell Biol. 2016, 18, 814-821. [CrossRef] [PubMed]

83. Zhao, J.; Zou, Y.; Liu, H.; Wang, H.; Zhang, H.; Hou, W.; Li, X.; Jia, X.; Zhang, J.; Hou, L.; et al. Teif associated centrosome activity is regulated by egf/pi3k/akt signaling. Biochim. Biophys. Acta 2014, 1843, 1851-1864. [CrossRef] [PubMed]

84. Enomoto, A.; Murakami, H.; Asai, N.; Morone, N.; Watanabe, T.; Kawai, K.; Murakumo, Y.; Usukura, J.; Kaibuchi, K.; Takahashi, M. Akt/pkb regulates actin organization and cell motility via girdin/ape. Dev. Cell 2005, 9, 389-402. [CrossRef] [PubMed] 
85. Mao, J.Z.; Jiang, P.; Cui, S.P.; Ren, Y.L.; Zhao, J.; Yin, X.H.; Enomoto, A.; Liu, H.J.; Hou, L.; Takahashi, M.; et al. Girdin locates in centrosome and midbody and plays an important role in cell division. Cancer Sci. 2012, 103, 1780-1787. [CrossRef] [PubMed]

86. Kamata, T.; Pritchard, C. Mechanisms of aneuploidy induction by ras and raf oncogenes. Am. J. Cancer Res. 2011, 1, 955-971. [PubMed]

87. Cui, Y.; Borysova, M.K.; Johnson, J.O.; Guadagno, T.M. Oncogenic b-raf(v600e) induces spindle abnormalities, supernumerary centrosomes, and aneuploidy in human melanocytic cells. Cancer Res. 2010, 70, 675-684. [CrossRef]

88. Denko, N.C.; Giaccia, A.J.; Stringer, J.R.; Stambrook, P.J. The human ha-ras oncogene induces genomic instability in murine fibroblasts within one cell cycle. Proc. Natl. Acad. Sci. USA 1994, 91, 5124-5128. [CrossRef]

89. Saavedra, H.I.; Fukasawa, K.; Conn, C.W.; Stambrook, P.J. Mapk mediates ras-induced chromosome instability. J. Biol. Chem. 1999, 274, 38083-38090. [CrossRef]

90. Knauf, J.A.; Ouyang, B.; Knudsen, E.S.; Fukasawa, K.; Babcock, G.; Fagin, J.A. Oncogenic ras induces accelerated transition through $\mathrm{g} 2 / \mathrm{m}$ and promotes defects in the g2 DNA damage and mitotic spindle checkpoints. J. Biol. Chem. 2006, 281, 3800-3809. [CrossRef]

91. Abulaiti, A.; Fikaris, A.J.; Tsygankova, O.M.; Meinkoth, J.L. Ras induces chromosome instability and abrogation of the DNA damage response. Cancer Res. 2006, 66, 10505-10512. [CrossRef] [PubMed]

92. Jinesh, G.G.; Sambandam, V.; Vijayaraghavan, S.; Balaji, K.; Mukherjee, S. Molecular genetics and cellular events of k-ras-driven tumorigenesis. Oncogene 2018, 37, 839-846. [CrossRef] [PubMed]

93. Berenjeno, I.M.; Pineiro, R.; Castillo, S.D.; Pearce, W.; McGranahan, N.; Dewhurst, S.M.; Meniel, V.; Birkbak, N.J.; Lau, E.; Sansregret, L.; et al. Oncogenic pik3ca induces centrosome amplification and tolerance to genome doubling. Nat. Commun. 2017, 8, 1773. [CrossRef] [PubMed]

94. Plo, I.; Lopez, B. Akt1 represses gene conversion induced by different genotoxic stresses and induces supernumerary centrosomes and aneuploidy in hamster ovary cells. Oncogene 2009, 28, 2231-2237. [CrossRef] [PubMed]

95. Jin, J.; Woodgett, J.R. Chronic activation of protein kinase bbeta/akt2 leads to multinucleation and cell fusion in human epithelial kidney cells: Events associated with tumorigenesis. Oncogene 2005, 24, 5459-5470. [CrossRef] [PubMed]

96. Peterson, T.R.; Laplante, M.; Van Veen, E.; Van Vugt, M.A.; Thoreen, C.C.; Sabatini, D.M. Mtorc1 regulates cytokinesis through activation of rho-rock signaling. arXiv 2012, arXiv:1506.04437v1. Available online: https://arxiv.org/abs/1506.04437 (accessed on 1 August 2019).

97. Moniz, L.S.; Surinova, S.; Ghazaly, E.; Velasco, L.G.; Haider, S.; Rodriguez-Prados, J.C.; Berenjeno, I.M.; Chelala, C.; Vanhaesebroeck, B. Phosphoproteomic comparison of pik3ca and pten signalling identifies the nucleotidase $\mathrm{nt5c}$ as a novel akt substrate. Sci. Rep. 2017, 7, 39985. [CrossRef] [PubMed]

98. Kiselev, V.Y.; Juvin, V.; Malek, M.; Luscombe, N.; Hawkins, P.; Le Novere, N.; Stephens, L. Perturbations of pip3 signalling trigger a global remodelling of mrna landscape and reveal a transcriptional feedback loop. Nucleic Acids Res. 2015, 43, 9663-9679. [CrossRef] [PubMed]

99. Vinayagam, A.; Kulkarni, M.M.; Sopko, R.; Sun, X.; Hu, Y.; Nand, A.; Villalta, C.; Moghimi, A.; Yang, X.; Mohr, S.E.; et al. An integrative analysis of the inr/pi3k/akt network identifies the dynamic response to insulin signaling. Cell Rep. 2016, 16, 3062-3074. [CrossRef] [PubMed]

100. Nam, H.J.; Chae, S.; Jang, S.H.; Cho, H.; Lee, J.H. The pi3k-akt mediates oncogenic met-induced centrosome amplification and chromosome instability. Carcinogenesis 2010, 31, 1531-1540. [CrossRef] [PubMed]

101. Celton-Morizur, S.; Merlen, G.; Couton, D.; Margall-Ducos, G.; Desdouets, C. The insulin/akt pathway controls a specific cell division program that leads to generation of binucleated tetraploid liver cells in rodents. J. Clin. Investig. 2009, 119, 1880-1887. [CrossRef] [PubMed]

102. Hou, S.Q.; Ouyang, M.; Brandmaier, A.; Hao, H.; Shen, W.H. Pten in the maintenance of genome integrity: From DNA replication to chromosome segregation. Bioessays 2017, 39, 1700082. [CrossRef] [PubMed]

103. Vanhaesebroeck, B.; Leevers, S.J.; Ahmadi, K.; Timms, J.; Katso, R.; Driscoll, P.C.; Woscholski, R.; Parker, P.J.; Waterfield, M.D. Synthesis and function of 3-phosphorylated inositol lipids. Annu. Rev. Biochem. 2001, 70, 535-602. [CrossRef] [PubMed]

104. Campa, C.C.; Martini, M.; De Santis, M.C.; Hirsch, E. How pi3k-derived lipids control cell division. Front. Cell Dev. Biol. 2015, 3, 61. [CrossRef] [PubMed] 
105. Garcia, Z.; Kumar, A.; Marques, M.; Cortes, I.; Carrera, A.C. Phosphoinositide 3-kinase controls early and late events in mammalian cell division. EMBO J. 2006, 25, 655-661. [CrossRef] [PubMed]

106. Jones, S.M.; Klinghoffer, R.; Prestwich, G.D.; Toker, A.; Kazlauskas, A. Pdgf induces an early and a late wave of pi 3-kinase activity, and only the late wave is required for progression through g1. Curr. Biol. 1999, 9, 512-521. [CrossRef]

107. Marques, M.; Kumar, A.; Cortes, I.; Gonzalez-Garcia, A.; Hernandez, C.; Moreno-Ortiz, M.C.; Carrera, A.C. Phosphoinositide 3-kinases p110alpha and p110beta regulate cell cycle entry, exhibiting distinct activation kinetics in g1 phase. Mol. Cell. Biol. 2008, 28, 2803-2814. [CrossRef] [PubMed]

108. Shtivelman, E.; Sussman, J.; Stokoe, D. A role for pi 3-kinase and pkb activity in the g2/m phase of the cell cycle. Curr. Biol. 2002, 12, 919-924. [CrossRef]

109. Jones, S.M.; Kazlauskas, A. Growth-factor-dependent mitogenesis requires two distinct phases of signalling. Nat. Cell Biol. 2001, 3, 165-172. [CrossRef]

110. Klippel, A.; Escobedo, M.A.; Wachowicz, M.S.; Apell, G.; Brown, T.W.; Giedlin, M.A.; Kavanaugh, W.M.; Williams, L.T. Activation of phosphatidylinositol 3-kinase is sufficient for cell cycle entry and promotes cellular changes characteristic of oncogenic transformation. Mol. Cell. Biol. 1998, 18, 5699-5711. [CrossRef]

111. Alvarez, B.; Martinez, A.C.; Burgering, B.M.; Carrera, A.C. Forkhead transcription factors contribute to execution of the mitotic programme in mammals. Nature 2001, 413, 744-747. [CrossRef]

112. Yuan, T.L.; Wulf, G.; Burga, L.; Cantley, L.C. Cell-to-cell variability in pi3k protein level regulates pi3k-akt pathway activity in cell populations. Curr. Biol. 2011, 21, 173-183. [CrossRef] [PubMed]

113. Sizek, H.; Hamel, A.; Deritei, D.; Campbell, S.; Ravasz Regan, E. Boolean model of growth signaling, cell cycle and apoptosis predicts the molecular mechanism of aberrant cell cycle progression driven by hyperactive pi3k. PLoS Comput. Biol. 2019, 15, e1006402. [CrossRef] [PubMed]

114. Sharma, S.V.; Lee, D.Y.; Li, B.; Quinlan, M.P.; Takahashi, F.; Maheswaran, S.; McDermott, U.; Azizian, N.; Zou, L.; Fischbach, M.A.; et al. A chromatin-mediated reversible drug-tolerant state in cancer cell subpopulations. Cell 2010, 141, 69-80. [CrossRef] [PubMed]

115. Ramirez, M.; Rajaram, S.; Steininger, R.J.; Osipchuk, D.; Roth, M.A.; Morinishi, L.S.; Evans, L.; Ji, W.; Hsu, C.H.; Thurley, K.; et al. Diverse drug-resistance mechanisms can emerge from drug-tolerant cancer persister cells. Nat. Commun. 2016, 7, 10690. [CrossRef] [PubMed]

116. Astle, M.V.; Hannan, K.M.; Ng, P.Y.; Lee, R.S.; George, A.J.; Hsu, A.K.; Haupt, Y.; Hannan, R.D.; Pearson, R.B. Akt induces senescence in human cells via mtorc1 and p53 in the absence of DNA damage: Implications for targeting mtor during malignancy. Oncogene 2012, 31, 1949-1962. [CrossRef] [PubMed]

117. Kim, J.S.; Lee, C.; Bonifant, C.L.; Ressom, H.; Waldman, T. Activation of p53-dependent growth suppression in human cells by mutations in pten or pik3ca. Mol. Cell. Biol. 2007, 27, 662-677. [CrossRef] [PubMed]

118. Ying, Z.; Sandoval, M.; Beronja, S. Oncogenic activation of pi3k induces progenitor cell differentiation to suppress epidermal growth. Nat. Cell Biol. 2018, 20, 1256-1266. [CrossRef]

119. Kennedy, A.L.; Morton, J.P.; Manoharan, I.; Nelson, D.M.; Jamieson, N.B.; Pawlikowski, J.S.; McBryan, T.; Doyle, B.; McKay, C.; Oien, K.A.; et al. Activation of the pik3ca/akt pathway suppresses senescence induced by an activated ras oncogene to promote tumorigenesis. Mol. Cell 2011, 42, 36-49. [CrossRef]

120. Onishi, K.; Higuchi, M.; Asakura, T.; Masuyama, N.; Gotoh, Y. The pi3k-akt pathway promotes microtubule stabilization in migrating fibroblasts. Genes Cells 2007, 12, 535-546. [CrossRef]

121. Gasic, I.; Boswell, S.A.; Mitchison, T.J. Tubulin mrna stability is sensitive to change in microtubule dynamics caused by multiple physiological and toxic cues. PLoS Biol. 2019, 17, e3000225. [CrossRef]

122. Akhmanova, A.; Hoogenraad, C.C.; Drabek, K.; Stepanova, T.; Dortland, B.; Verkerk, T.; Vermeulen, W.; Burgering, B.M.; De Zeeuw, C.I.; Grosveld, F.; et al. Clasps are clip-115 and -170 associating proteins involved in the regional regulation of microtubule dynamics in motile fibroblasts. Cell 2001, 104, 923-935. [CrossRef]

123. Di Paolo, G.; Antonsson, B.; Kassel, D.; Riederer, B.M.; Grenningloh, G. Phosphorylation regulates the microtubule-destabilizing activity of stathmin and its interaction with tubulin. FEBS Lett. 1997, 416, 149-152. [CrossRef]

124. Wik, E.; Birkeland, E.; Trovik, J.; Werner, H.M.; Hoivik, E.A.; Mjos, S.; Krakstad, C.; Kusonmano, K.; Mauland, K.; Stefansson, I.M.; et al. High phospho-stathmin(serine38) expression identifies aggressive endometrial cancer and suggests an association with pi3k inhibition. Clin. Cancer Res. 2013, 19, 2331-2341. [CrossRef] [PubMed] 
125. Andersen, J.N.; Sathyanarayanan, S.; Di Bacco, A.; Chi, A.; Zhang, T.; Chen, A.H.; Dolinski, B.; Kraus, M.; Roberts, B.; Arthur, W.; et al. Pathway-based identification of biomarkers for targeted therapeutics: Personalized oncology with pi3k pathway inhibitors. Sci. Transl. Med. 2010, 2, 43ra55. [CrossRef] [PubMed]

126. Cross, D.A.; Alessi, D.R.; Cohen, P.; Andjelkovich, M.; Hemmings, B.A. Inhibition of glycogen synthase kinase-3 by insulin mediated by protein kinase b. Nature 1995, 378, 785-789. [CrossRef] [PubMed]

127. Buttrick, G.J.; Beaumont, L.M.; Leitch, J.; Yau, C.; Hughes, J.R.; Wakefield, J.G. Akt regulates centrosome migration and spindle orientation in the early drosophila melanogaster embryo. J. Cell Biol. 2008, 180, 537-548. [CrossRef] [PubMed]

128. Buttrick, G.J.; Wakefield, J.G. Pi3-k and gsk-3: Akt-ing together with microtubules. Cell Cycle 2008, 7, 2621-2625. [CrossRef] [PubMed]

129. Mitsushima, M.; Toyoshima, F.; Nishida, E. Dual role of cdc42 in spindle orientation control of adherent cells. Mol. Cell. Biol. 2009, 29, 2816-2827. [CrossRef] [PubMed]

130. Toyoshima, F.; Matsumura, S.; Morimoto, H.; Mitsushima, M.; Nishida, E. Ptdins $(3,4,5)$ p3 regulates spindle orientation in adherent cells. Dev. Cell 2007, 13, 796-811. [CrossRef] [PubMed]

131. Silio, V.; Redondo-Munoz, J.; Carrera, A.C. Phosphoinositide 3-kinase beta regulates chromosome segregation in mitosis. Mol. Biol. Cell 2012, 23, 4526-4542. [CrossRef]

132. Paranavitane, V.; Coadwell, W.J.; Eguinoa, A.; Hawkins, P.T.; Stephens, L. Ll5beta is a phosphatidylinositol $(3,4,5)$-trisphosphate sensor that can bind the cytoskeletal adaptor, gamma-filamin. J. Biol. Chem. 2003, 278, 1328-1335. [CrossRef] [PubMed]

133. Lansbergen, G.; Grigoriev, I.; Mimori-Kiyosue, Y.; Ohtsuka, T.; Higa, S.; Kitajima, I.; Demmers, J.; Galjart, N.; Houtsmuller, A.B.; Grosveld, F.; et al. Clasps attach microtubule plus ends to the cell cortex through a complex with 1l5beta. Dev. Cell 2006, 11, 21-32. [CrossRef] [PubMed]

134. Naguib, A.; Bencze, G.; Cho, H.; Zheng, W.; Tocilj, A.; Elkayam, E.; Faehnle, C.R.; Jaber, N.; Pratt, C.P.; Chen, M.; et al. Pten functions by recruitment to cytoplasmic vesicles. Mol. Cell 2015, 58, 255-268. [CrossRef] [PubMed]

135. Fujiwara, Y.; Hosokawa, Y.; Watanabe, K.; Tanimura, S.; Ozaki, K.; Kohno, M. Blockade of the phosphatidylinositol-3-kinase-akt signaling pathway enhances the induction of apoptosis by microtubule-destabilizing agents in tumor cells in which the pathway is constitutively activated. Mol. Cancer Ther. 2007, 6, 1133-1142. [CrossRef] [PubMed]

136. Bohnacker, T.; Prota, A.E.; Beaufils, F.; Burke, J.E.; Melone, A.; Inglis, A.J.; Rageot, D.; Sele, A.M.; Cmiljanovic, V.; Cmiljanovic, N.; et al. Deconvolution of buparlisib's mechanism of action defines specific pi3k and tubulin inhibitors for therapeutic intervention. Nat. Commun. 2017, 8, 14683. [CrossRef] [PubMed]

137. Brachmann, S.M.; Kleylein-Sohn, J.; Gaulis, S.; Kauffmann, A.; Blommers, M.J.; Kazic-Legueux, M.; Laborde, L.; Hattenberger, M.; Stauffer, F.; Vaxelaire, J.; et al. Characterization of the mechanism of action of the pan class i pi3k inhibitor nvp-bkm120 across a broad range of concentrations. Mol. Cancer Ther. 2012, 11, 1747-1757. [CrossRef] [PubMed]

138. Mardin, B.R.; Isokane, M.; Cosenza, M.R.; Kramer, A.; Ellenberg, J.; Fry, A.M.; Schiebel, E. Egf-induced centrosome separation promotes mitotic progression and cell survival. Dev. Cell 2013, 25, 229-240. [CrossRef] [PubMed]

139. Khwaja, A.; Rodriguez-Viciana, P.; Wennstrom, S.; Warne, P.H.; Downward, J. Matrix adhesion and ras transformation both activate a phosphoinositide 3-oh kinase and protein kinase b/akt cellular survival pathway. EMBO J. 1997, 16, 2783-2793. [CrossRef] [PubMed]

140. Comaills, V.; Kabeche, L.; Morris, R.; Buisson, R.; Yu, M.; Madden, M.W.; LiCausi, J.A.; Boukhali, M.; Tajima, K.; Pan, S.; et al. Genomic instability is induced by persistent proliferation of cells undergoing epithelial-to-mesenchymal transition. Cell Rep. 2016, 17, 2632-2647. [CrossRef] [PubMed]

141. Gergely, F.; Karlsson, C.; Still, I.; Cowell, J.; Kilmartin, J.; Raff, J.W. The tacc domain identifies a family of centrosomal proteins that can interact with microtubules. Proc. Natl. Acad. Sci. USA 2000, 97, 14352-14357. [CrossRef] [PubMed]

142. Peset, I.; Vernos, I. The tacc proteins: Tacc-ling microtubule dynamics and centrosome function. Trends Cell Biol. 2008, 18, 379-388. [CrossRef] [PubMed]

143. Zwang, Y.; Jonas, O.; Chen, C.; Rinne, M.L.; Doench, J.G.; Piccioni, F.; Tan, L.; Huang, H.T.; Wang, J.; Ham, Y.J.; et al. Synergistic interactions with pi3k inhibition that induce apoptosis. eLife 2017, 6, e24523. [CrossRef] [PubMed] 
144. Cully, M.; Shiu, J.; Piekorz, R.P.; Muller, W.J.; Done, S.J.; Mak, T.W. Transforming acidic coiled coil 1 promotes transformation and mammary tumorigenesis. Cancer Res. 2005, 65, 10363-10370. [CrossRef] [PubMed]

145. Gomez-Baldo, L.; Schmidt, S.; Maxwell, C.A.; Bonifaci, N.; Gabaldon, T.; Vidalain, P.O.; Senapedis, W.; Kletke, A.; Rosing, M.; Barnekow, A.; et al. Tacc3-tsc2 maintains nuclear envelope structure and controls cell division. Cell Cycle 2010, 9, 1143-1155. [CrossRef] [PubMed]

146. Singh, D.; Chan, J.M.; Zoppoli, P.; Niola, F.; Sullivan, R.; Castano, A.; Liu, E.M.; Reichel, J.; Porrati, P.; Pellegatta, S.; et al. Transforming fusions of FGFR and TACC genes in human glioblastoma. Science 2012, 337, 1231-1235. [CrossRef] [PubMed]

147. Shah, N.; Kumar, S.; Zaman, N.; Pan, C.C.; Bloodworth, J.C.; Lei, W.; Streicher, J.M.; Hempel, N.; Mythreye, K.; Lee, N.Y. Tak1 activation of alpha-tat1 and microtubule hyperacetylation control akt signaling and cell growth. Nat. Commun. 2018, 9, 1696. [CrossRef] [PubMed]

148. Gerstung, M.; Jolly, C.; Leshchiner, I.; Dentro, S.C.; Gonzalez, S.; Rosebrock, D.; Mitchell, T.J.; Rubanova, Y.; Anur, P.; Yu, K.; et al. The evolutionary history of 2,658 cancers. bioRxiv 2018, 161562. [CrossRef]

149. Jamal-Hanjani, M.; Wilson, G.A.; McGranahan, N.; Birkbak, N.J.; Watkins, T.B.K.; Veeriah, S.; Shafi, S.; Johnson, D.H.; Mitter, R.; Rosenthal, R.; et al. Tracking the evolution of non-small-cell lung cancer. N. Engl. J. Med. 2017, 376, 2109-2121. [CrossRef]

150. Shaw, J.A.; Guttery, D.S.; Hills, A.; Fernandez-Garcia, D.; Page, K.; Rosales, B.M.; Goddard, K.S.; Hastings, R.K.; Luo, J.; Ogle, O.; et al. Mutation analysis of cell-free DNA and single circulating tumor cells in metastatic breast cancer patients with high circulating tumor cell counts. Clin. Cancer Res. 2017, 23, 88-96. [CrossRef]

151. Semple, R.K.; Vanhaesebroeck, B. Lessons for cancer drug treatment from tackling a non-cancerous overgrowth syndrome. Nature 2018, 558, 523-525. [CrossRef]

152. Fisher, R.; Horswell, S.; Rowan, A.; Salm, M.P.; de Bruin, E.C.; Gulati, S.; McGranahan, N.; Stares, M.; Gerlinger, M.; Varela, I.; et al. Development of synchronous vhl syndrome tumors reveals contingencies and constraints to tumor evolution. Genome Biol. 2014, 15, 433. [CrossRef] [PubMed]

153. Venkatesan, S.; Birkbak, N.J.; Swanton, C. Constraints in cancer evolution. Biochem. Soc. Trans. 2017, 45, 1-13. [CrossRef] [PubMed]

154. Madsen, R.R.; Vanhaesebroeck, B.; Semple, R.K. Cancer-associated pik3ca mutations in overgrowth disorders. Trends Mol. Med. 2018, 24, 856-870. [CrossRef] [PubMed]

155. Venot, Q.; Blanc, T.; Rabia, S.H.; Berteloot, L.; Ladraa, S.; Duong, J.P.; Blanc, E.; Johnson, S.C.; Hoguin, C.; Boccara, O.; et al. Targeted therapy in patients with pik3ca-related overgrowth syndrome. Nature 2018, 558, 540-546. [CrossRef] [PubMed]

156. Knouse, K.A.; Lopez, K.E.; Bachofner, M.; Amon, A. Chromosome segregation fidelity in epithelia requires tissue architecture. Cell 2018, 175, 200-211. [CrossRef] [PubMed]

(C) 2019 by the authors. Licensee MDPI, Basel, Switzerland. This article is an open access article distributed under the terms and conditions of the Creative Commons Attribution (CC BY) license (http://creativecommons.org/licenses/by/4.0/). 